\title{
ANALISIS DAN STRATEGI PENGEMBANGAN USAHA BUDIDAYA LELE DUMBO \\ DI KELURAHAN TEMBILAHAN HULU KECAMATAN TEMBILAHAN KABUPATEN INDRAGIRI HILIR
}

\author{
Yeni Afiza ${ }^{1}$, Sri Puji Pangestuti1 \\ 1Program Studi Agribisnis Fakultas Pertanian UNISI \\ Email: yeni_afiza@yahoo.co.id
}

\begin{abstract}
ABSTRAK
Penelitian ini bertujuan : (1) untuk mengetahui biaya, pendapatan, keuntungan dan efisiensi dalam usaha budidaya lele dumbo, (2) untuk merumuskan strategi yang alternative yang dapat diterapkan dalam mengembangkan budidaya ikan lele dumbo. Metode yang digunakan untuk menganalisis data dalam penelitian ini adalah (1) dengan analisis biaya, pendapatan, keuntungan serta efisiensi usaha. (2) Analisis SWOT. Penelitian ini dilakukan dengan menggunakan metode dokumentasi dan wawancara langsung dengan kuisioner. Hasil penelitian menunjukkan bahwa : (1) biaya tidak tetap sebesar Rp.4.346.510,00/produksi. Serta biaya tetap sebesar Rp.2.582,363,33/produksi dengan rata - rata penerimaan yang diperoleh sebesar Rp. 10.362.880,00/produksi, rata-rata keuntungan yang diperoleh adalah sebesar Rp.3.509.047,67/produksi, rata - rata pendapatan kerja keluarga sebesar Rp. 5.371.410,00/produksi dan nilai RCR adalah sebesar 1,49 (2) Dari analisis SWOT, diperoleh hasil perumusan strategi pada Kuadran I dengan nilai Peluang 1,31 dan Kekuatan 2,54.
\end{abstract}

Kata Kunci : Keuntungan, Efisiensi, Ikan lele dumbo, SWOT.

\begin{abstract}
The purposes of research were : (1) to determine the cost net income and efficiency of catfish farming, (2) to formulate of alternative strategy for developt of business catfish farming. The method of data analysis are (1) Total cost, revenue, profit and Effeciency analysis, (2) SWOT analysis.This research was conducted using the method of direct documentation and interview with questionnaires. The research results show that : (1) Total cost of business catfish farming variabel cost Rp.4.346.510,00/production and fix cost Rp.2.582,363,33/production, average revenue is Rp. 10.362.880,00/produktion, average net income is Rp. 3.509.047,67/production, family income is Rp.5.371.410,00/production and RCR equal to 1,49. (2) From SWOT analysis, formulated strategy in Kuadran I with score of Opportunities is 1,31 and Strenght is 2,54 .
\end{abstract}

Keywords : Benefit, Effeciency, Catfish, SWOT. 


\section{PENDAHULUAN}

Ikan lele merupakan salah satu jenis ikan air tawar yang sudah dibudidayakan secara komersial oleh masyarakat Indonesia terutama di kabupaten Indragiri Hilir. Budidaya lele berkembang pesat dikarenakan dapat budidayakan di lahan dan sumber air terbatas dengan padat tebar tinggi, teknologi budidaya yang relatif mudah dikuasai oleh masyarakat, pemasarannya relatif mudah serta modal usaha yang dibutuhkan relatif rendah. Selain itu beberapa keunggulan lele dumbo sebagai komoditas budidaya diantaranya ikan ini dapat dipijahkan sepanjang tahun, memiliki fekunditas telur yang tinggi, dapat hidup pada kondisi air yang marjinal,dan memiliki efisiensi pakan yang tinggi.Lele juga kaya akan gizi 16yaitu protein sebesar $20 \%$ dan sangat baik untuk kesehatan karena tergolong makanan dengan kandungan lemak yang relatif rendah dan mineral yang tinggi. Dalam setiap 100 gram lele memiliki kandungan lemak hanya dua gram, jauh lebih rendah daripada daging sapi sebesar 14 gram apalagi daging ayam yaitu sebesar 25 gram (Departemen Kelautan dan Perikanan, 2003).

Usaha budidaya ikan lele dumbo di Kelurahan Tembilahan Hulu mengalami peningkatan produksi perikanan setiap tahunnya baik dari budidaya kolam maupun pemeliharaan diterpal,Kolam di peternakan ikan lele di Kelurahan Tembilahan Hulubiasanya digunakan untuk budidaya ikanair tawar. Usaha budidaya ikan lele dumbo memberikan prospek yang bagus untuk dikembangkan.
Permasalahan atau kendala yang sering dihadapi pembudidaya diantaranya pengelolaan bubidaya yang masih sederhana, selain itu sifat usaha yang bisa gagal panen karna ikan mati disebabkan cuaca yang tidakstabil, air yang kurangbersih, kepadatan ikan di kolam budidaya,sertasifat ikan yang kanibalisme sehingga mengurangi produksi dalam skala besar. Sedangkan keunggulan dari usaha budidaya ikan lele dumbo ini adalah hasil panennya yang dalam kapasitas besar bisa memenuhi kebutuhan lele bagi konsumen khususnya rumah makan pecel lele. Selain itu lele hasil panen ikan lele ini adalah kualitas unggulan, dengan ukuran yang besar dan masih segar. Serta kapasitas produksi dari usaha lele pembudidaya kelurahan Tembilahan Hulu cenderung stabil.

Terdapat pula peluang yang dimiliki oleh pembudidaya ikan lele diantaranya ikan lele yang mengandung banyak zat gizi yang dbutuhkan oleh tubuh, sehingga konsumen berminat untuk terus mengkonsumsi ikan lele. Selain itu dengan banyaknya usaha warung makan yang berada Tembilahan, menjadikan permintaan terhadap ikan lele pun terus meningkat. Peluang lain yang dimiliki oleh pembudidaya adalah dengan mudahnya jalur transportasi tentu akan mempermudah pula bagi pembudidaya untuk mendistribusikan produknya untuk sampai ketangan konsumen. Namun terdapat pula ancaman yang dihadapi pembudidaya yaitu akan muncul pesaing - pesaing baru, selain itu dengan harga pakan yang terus meningkat akan memperkecil keuntungan yang didapat oleh pembudidaya. Dan isu yang beredar 
tentang ikan lele yang memicu tumbuhnya sel kanker yang akan membuat ketakutan konsumen untuk mengkonsumsi ikan lele.

Menghadapi situasi dan kondisi demikian maka untuk mengoptimalkan pemanfaatan potensi sumberdaya dan peluang usaha budidaya lele dumbo dalam rangka mendukung pembangunan dan peningkatan taraf hidup pembudidaya ikan lele dumbo, para pelaku input dan output usaha budidaya lele dumbo diperlukan cara efektif untuk pengembangan usaha budidaya lele dumbo. Tujuan dari penelitian ini adalah untuk mengetahui tingkat efesiensi usaha lele dumbo dan merumuskan strategi yang alternative yang dapat diterapkan dalam mengembangkan budidaya ikan lele dumbo.

\section{TINJAUAN PUSTAKA}

\subsection{Usaha Budidaya Lele Dumbo}

Ikan lele dombo mempunyai prospek bisnis yang sangat bagus. Hal ini didukung oleh rasa dagingnya yang gurih, bergizi tinggi, warnanya putih dan bertekstur halus. Selain itu ikan berkumis ini juga memiliki beberapa kelebihan, antara lain pertumbuhannya cepat meskipun dipelihara dengan kepadatan tinggi, ketahanan hidupnya tinggi, tidak 25 terlalu sulit dalam hal pakan karena termasuk jenis omnivora, teknologi budidayanya tidak terlalu rumit dan bisa dipelihara diberbagai lokasi, misalnya di kolam, sawah, empang atau mina padi. Keuntungan lain dari usaha budi daya lele adalah tidak perlu dilakukan secara integrated dalam satu unit usaha, dari pembenihan hingga pembesaran. Artinya pelaku usaha budi daya bisa memilih subsistem yang disukai, misalnya hanya menekuni usaha pendederan atau pembesaran (Anonim, 2002).

Tahap

pembesaran merupakan tahap pemeliharaan ikan lele untuk mencapai ukuran konsumsi. Persiapan kolam pembesaran sama dengan persiapan untuk kolam pendederan, tetapi tidak perlu dilakukan penyemprotan dengan pestisida. Pemelihaaraan berlangsung sekitar 2-3 bulan atau hingga empat bulan. Padat penebarannya $30-50$ ekor $/ \mathrm{m} 2$ atau 70 ekor/m2 untuk ikan lele ukuran 5-8 $\mathrm{cm}$. Sebagai pakan utama dapat diberikan pelet. Frekuensi pemberiannya bisa sesering mungkin, misalnya 2-3 kali dalam sehari. Pada tahap ini mortalitas ikan lele mencapai $30 \%(500 \mathrm{~kg} / 100 \mathrm{~m} 2)$ (Anonim, 2002).

\subsection{Penerimaan, Biaya dan Keuntungan}

Menurut Soekartawi (1990) peneriman tunai usahatani adalah nilai yang diterima dari penjualan produk usahatani. Sedangkan penerimaan ini merupakan hasil perkalian dari jumlah produk total dengan harga persatuan.

Klasifikasi biaya penting dalam membandingkan pendapatan untuk 27 mengetahui kebenaran jumlah biaya yang tertera pada pernyataan pendapatan (income statement) terdiri dari empat kategori, yaitu:

a. Biaya tetap (fixed cost) adalah biaya yang penggunaanya tidak habis dalam satu masa produksi yang termasuk dalam biaya ini antara lain adalah pajak tanah, pajak air, penyusutan alat, dan bangunan pertanian. 
b. Biaya variabel atau biaya-biaya berubah (variabel cost) adalah biaya yang besar kecilnya sangat tergantung pada biaya skala produksi. Yang termasuk kedalam biaya ini antara lain adalah : biaya untuk bibit, pupuk, pembasmi hama dan penyakit, buruh atau tenaga kerja upahan, biaya panen, biaya pengolahan tanah baik yang berupa kontrak maupun upah harian.

c. Biaya tunai dari biaya tetap dapat berupa pajak air dan pajak tanah. Sedangkan biaya tunai dari biaya variabel antara lain berupa pemakaian bibit, pupuk, obatobatan tenaga luar keluarga.

d. Biaya tidak tunai meliputi biaya tetap, biaya untuk tenaga kerja keluarga. Sedangkan yang termasuk biaya variabel antara lain biaya panen dan pengolahan tanah dari tenaga kerja keluarga(Fadholi, 1989).

Analisis dalam usahatani untuk menghitung pendapatan usahatani dapat dilakukan dengan dua pendekatan, yaitu :

a. Pendekatan pendapatan, digunakan jika usahatani yang dikelola bersifat subsisten atau tidak berorientasi keuntungan. Pendapatan merupakan pengurangan penerimaan dengan total biaya luar yang secara nyata dibayarkan untuk masukan dari luar.

b. Pendekatan keuntungan, digunakan jika usahatani yang dikelola bersifat komersial atau bertujuan untuk memaksimalkan keuntungan.

Keuntungan merupakan hasil dari penerimaan dikurangi dengan total biaya yang dikeluarkan untuk masukan dari luar dan masukan milik sendiri, yaitu sewa tanah milik petani, upah tenaga kerja keluarga dan bunga modal milik sendiri (Djuwari, 1994).

\subsection{Analisis SWOT}

\subsubsection{Analisis Situasi Internal}

Analisis Kekuatan (Strength)

Setiap perusahaan perlu menilai kekuatan dan kelemahannya dibandingkan para pesaingnya. Penilaian tersebut dapat didasarkan pada faktor-faktor seperti teknologi, sumber daya finansial, kemampuan kemanufakturan, kekuatan pemasaran dan basis pelanggan yang dimiliki. Strength adalah keahlian atau kelebihan yang dimilki oleh perusahaan pesaing.

Analisis Kelemahan (Weakness) Merupakan keadaan perusahaan dalam menghadapi pesaing mempunyai keterbatasan dan kekurangan serta kemampuan menguasai pasar, sumber daya serta keahlian. Keterbatasan dan kekurangan dalam hal sumber, keterampilan dan kemampuan menjadi penghalang serius bagi kinerja organisasi yang memuaskan. Keterbatasan dan kekurangan kemampuan bias terlihat pada sarana dan prasarana yang dimiliki atau tidak dimiliki,kemampuan manajerial yang rendah, keterampilan pemasaran yang tidak sesuai dengan tuntutan pasar, produk yang tidak atau kurang diminta oleh para pengguna atau calon pengguna dan tingkat perolehan keuntungan yang kurang memadai.

\subsubsection{Analisis Situasi Eksternal}

Analisis

Peluang

(Opportunity) Setiap perusahaan memiliki sumber daya yang 
membedakan dirinya dengan perusahaan lain. Peluang dan terobosan atau keunggulan bersaing tertentu dan beberapa peluang membutuhkan sejumlah besar modal unutuk dapat dimanfaatkan. Di lain pihak, perusahaan-perusahaan baru bermunculan. Peluang pemasaran adalah suatu tempat dimana perusahaan dapat beroperasi secara menguntungkan.

Analisis Ancaman (Threats)

Ancaman adalah tantangan yang diperlihatkan atau suatu perkembangan yang tidak menguntungkan dalam lingkungan yang menyebabkan kemunduran kedudukan perusahaan. Pengertian ancaman merupakan kebalikan pengertian peluang. Ancaman adalah faktor-faktor lingkungan yang tidak menguntungkan suatu bisnis.

\section{METODOLOGI PENELITIAN}

\subsection{Waktu dan Tempat Penelitian}

Penelitian ini dilaksanakan di Lokasi Usaha Budidaya Ikan Lele di Kel.Tembilahan Hulu Kec. Tembilahan Hulu Kabupaten Inhil Riau. Pemilihan lokasi penelitian dilakukan secara sengaja (purposive) dengan alasan bahwa usaha Budidaya Ikan lele di Kelurahan Tembilahan Hulu sudah lama beroperasi dan setiap pembudidaya lele dumbo mengalami peningkatan dalam pengembangan usahanya. Penelitian ini dilakukan bulan Juni sampai dengan bulan Agustus 2017.

\subsection{Metode Pengambilan Sampel}

Penelitian ini menggunakan teknik sampling nonprobability sampling dengan jenis sampling jenuh yaitu teknik penentuan sampel bila anggota populasi digunakan sebagai sampel. Hal ini sering dilakukan bila jumlah populasi relative kecil, kurang dari 30 orang, atau penelitian yang ingin membuat generalisasi dengan kesalahan yang sangat kecil. Peneliti menggunakan teknik sampling ini karena jumlah populasi sebanyak 5 orang. Menurut Ridwan (2012), "Sampling jenuh ialah teknik pengambilan sampel apabila semua populasi digunakan sebagai sampel dan dikenal juga dengan istilah sensus". Dalam penelitian ini, melihat jumlah populasi sebanyak 5 orang maka semua anggota populasi dijadikan sampel penelitian. Oleh karena itu, sampel yang diambil untuk penelitian ini sebanyak 5 orang.

\subsection{Metode Analisis Data}

\subsubsection{Analisis Usaha}

Menurut Rahim dan Hastuti ( 2007 ) total biaya atau total cost adalah jumlah dari biaya tetap atau fixed cost dan biaya tidak tetap atau variabel cost. Untuk menghitung total biaya ( total cost ) dapat dirumuskan dengan rumus :

$\mathrm{TC}=\mathrm{TFC}+\mathrm{TVC}$

Dimana :

$\begin{aligned} \mathrm{TC} & =\text { Biaya Total }(\mathrm{Rp} / \text { produksi }) \\ \mathrm{TFC}= & \text { Biaya tetap total }(\mathrm{Rp} / \\ & \text { produksi }) \\ \mathrm{TVC}= & \text { Biaya variabel } \\ & \text { produksi }) .\end{aligned}$

Menurut Soekartawi (1995), pendapatan kotor merupakan total nilai produksi usahatani dalam jangka waktu tertentu dikali dengan harga jual. Untuk menghitung pendapatan kotor (total revenue) dapat digunakan rumus : 
$\mathrm{TR}=\mathrm{Y} . \mathrm{Py}$

Di mana:

$$
\begin{aligned}
\mathrm{TR}= & \text { Total penerimaan }(\mathrm{Rp} / \\
& \text { produksi }) \\
\mathrm{Py}= & \text { Harga } \\
\mathrm{Y}= & \begin{array}{l}
\text { Produksi ikan lele yang } \\
\text { diperoleh }
\end{array}
\end{aligned}
$$

Rahim dan Hastuti (2007) mengemukakan bahwa pendapatan bersih yaitu selisih antara total penerimaan dengan total biaya yang dikeluarkan selama proses produksi.Untuk menghitung pendapatan bersih dapat digunakan rumus :

$\pi=\mathrm{TR}-\mathrm{TC}$

Di mana:

$\Pi=$ Pendapatan bersih $(\mathrm{Rp} /$ produksi)

$\mathrm{TR}=$ Total penerimaan $(\mathrm{Rp} /$ produksi)

$\mathrm{TC}=$ Total biaya $(\mathrm{Rp} /$ produksi)

Rahim dan Hastuti (2007) mengemukakan analisis $\mathrm{R} / \mathrm{C}$ Ratio merupakan perbandingan (ratio atau nisbah) antara penerimaan (revenue) dan biaya (cost). Pernyataan tersebut dapat dinyatakan dalam rumus sebagai berikut :

$\mathrm{RCR}=\mathrm{TR} / \mathrm{TC}$

Dimana:

$$
\begin{aligned}
\mathrm{TR} & =\underset{\text { Total Revenue }}{\text { produksi }}(\mathrm{Rp} / \\
\mathrm{TC} & =\text { Total cost }(\mathrm{Rp} / \text { produksi })
\end{aligned}
$$

Kriteria keputusan :

$\mathrm{R} / \mathrm{C}>1$ : Usaha budidaya ikan lele menguntungkan

$\mathrm{R} / \mathrm{C}<1$ : Usaha budidaya ikan lele rugi

$\mathrm{R} / \mathrm{C}=1$ : Usaha budidaya ikan lele impas (tidak untung dan tidak rugi )

\subsubsection{Analisis SWOT}

\section{Matrik Faktor Strategi Internal (IFAS)}

Tahapan penentuan faktor strategi internal adalah sebagai berikut :

1. Menentukan faktor-faktor yang menjadi kekuatan serta kelemahan perusahaan dalam kolom 1.

2. Beri bobot dengan alternative nilai 1 - 5 dimana :

$1=$ Tidak Penting

$2=$ Kurang penting

$3=$ Biasa saja

$4=$ Penting

$5=$ Sangat Penting

Dari alternative nilai tersebut, selanjutnya dibuat persentase bobot sehingga besarnya bobot antara 0,0 sampai 1,0 ( semua bobot totalnya maksimal 1,0 )

3. Menghitung rating (dalam kolom 3) untuk masing-masing faktor dengan memberikan skala mulai dari 4 (outstanding) sampai dengan 1 (poor), 38 berdasarkan pengaruh faktor tersebut terhadap kondisi perusahaan yang bersangkutan.

4. Kalikan bobot pada kolom 2 dengan rating pada kolom 3 untuk memperoleh faktor pembobotan dalam kolom 4 . Hasilnya berupa skor pembobotan untuk masingmasing faktor yang nilainya bervariasi mulai dari 4,0 (outstanding) sampai dengan 1,0 (poor).

5. Gunakan kolom 5 untuk memberikan komentar atau catatan mengapa faktor-faktor tertentu dipilih dan bagaimana skor pembobotannya dihitung.

6. Jumlahkan skor pembobotan (pada kolom 4), untuk memperoleh jumlah total skor 
pembobotan bagi peternakanikan yang bersangkutan. Nilai total ini menunjukkan bagaimana peternakanikan tertentu bereaksi terhadap faktor-faktor strategis internalnya. Total skor ini dapat digunakan

untuk membandingkan peternakanikan ini dengan peternakanikan lainnya dalam kelompok industri yang sama (Rangkuti, 2006 : 24).

Tabel 1. Form Matrik IFAS (Internal Strategic Factor Analysis Summary,

\begin{tabular}{lllll}
\hline & Kekuatan & Bobot & Rating & Skor \\
\hline 1. & & & & \\
2. & & & & \\
3. & & & & \\
4. & & Bobot & Rating & Skor \\
\hline 1. & Kelemahan & & & \\
2. & & & & \\
3. & & & & \\
4. & & & & \\
\hline
\end{tabular}

\section{Analisis Faktor Strategi Eksternal (EFAS)}

Berikut ini adalah cara-cara penentuan Faktor Strategi Eksternal (EFAS) :

1. Susunlah dalam kolom 1 (5 sampai dengan 10 peluang dan ancaman).

2. Beri bobot dengan alternative nilai 1 - 5 dimana :

$1=$ Tidak Penting

$2=$ Kurang penting

$3=$ Biasa saja

$4=$ Penting

$5=$ Sangat Penting

Dari alternative nilai tersebut, selanjutnya dibuat persentase bobot sehingga besarnya bobot antara 0,0 sampai 1,0 (semua bobot totalnya maksimal 1,0$)$

3. Hitung rating (dalam kolom 3) untuk masing-masing faktor dengan memberikan skala mulai dari 4 (outstanding) sampai dengan 1 (poor) berdasarkan pengaruh faktor tersebut terhadap kondisi perusahaan yang bersangkutan. Pemberian nilai rating untuk faktor peluang bersifat positif (peluang yang semakin besar diberi rating 4 , tetapi jika peluangnya kecil diberi rating 1). Pemberian nilai rating ancaman adalah kebalikannya. Misalnya, jika nilai ancamannya sangat besar, ratingnya adalah 1 . Sebaliknya, jika nilai ancamannya sedikit ratingnya 4.

4. Kalikan bobot pada kolom 2 dengan rating pada kolom 3, untuk memperoleh faktor pembobotan dalam kolom.

5. Hasilnya berupa skor pembobotan untuk masingmasing faktor yang nilainya bervariasi mulai dari 4,0 (outstanding) sampai dengan 1 (poor). 4. Gunakan kolom 5 untuk memberikan komentar atau catatan mengapa faktor-faktor tertentu dipilih dan bagaimana skor pembobotannya dihitung.

6. Jumlahkan skor pembobotan (pada kolom 4), untuk 
memperoleh jumlah total skor pembobotan bagi perusahaan yang bersangkutan. Nilai total ini menunjukkan bagaimana peternakan ikan tertentu bereaksi terhadap faktor-faktor strategis eksternalnya. Total skor ini dapat digunakan untuk membandingkan peternakanikan ini dengan peternakanikan lainnya dalam kelompok industri yang sama (Rangkuti, $2006: 22$ ).

Tabel 2. Form Matrik EFAS (EksternalStrategic Factor Analysis Summary)

\begin{tabular}{lllll}
\hline & Peluang & Bobot & Rating & Skor \\
\hline 1. & & & & \\
2. & & & & \\
3. & & & & \\
4. & Ancaman & Bobot & Rating & Skor \\
\hline 1. & & & & \\
2. & & & \\
3. & & & \\
4. & & & \\
\hline
\end{tabular}

Posisi perusahaan dapat strategi diversifikasi, Kuadran III dikelompokkan dalam empat strategi turn around dan kuadran IV kuadran, yaitu kuadran I,II,III dan strategi defensif. Diagram grand IV. Kuadran I strategi yang sesuai strategi disajikan pada Gambar 2. adalah strategi agresif, kuadran II

III. mendukung strategi agresif turn - arround

\section{KELEMAHAN Mendeknag}

IV. Mendukung strategi defensive

\section{BERBAGAI PELUANG}

I. Mendukung strategi

\section{KELEMAHAN \\ EKSTERNAL}

II. strategi diverifikasi

\section{BERBAGAI}

ANCAMAN

Gambar 1. Diagram Grand Strategi 
IV. HASIL DAN PEMBAHASAN

\subsection{Analisis Usaha Budidaya Ikan lele dumbo 4.1.1 Biaya Produksi}

Biaya adalah sejumlah nilai uang yang dikeluarkan oleh pembudidaya ikan lele untuk membiayai kegiatan usaha budidayanya. Biaya yang diperhitungkan dalam penelitian ini adalah biaya yang benar-benar dikeluarkan oleh pembudidaya dalam usaha budidaya lele dumbo selama satu musim budidaya pada Agustus 2017- Oktober 2017. Meliputi biaya pembelian sarana produksi dan biaya lain - lain. Besarnya biaya yang dikeluarkan dalam usaha budidaya ikan lele dumbo milik pembudidaya lele dumbo di kel.Tembilahan Hulu dilihat pada Tabel 3 .

Tabel 3. Analisis Biaya Produksi Usaha Budidaya Ikan Lele Dumbo

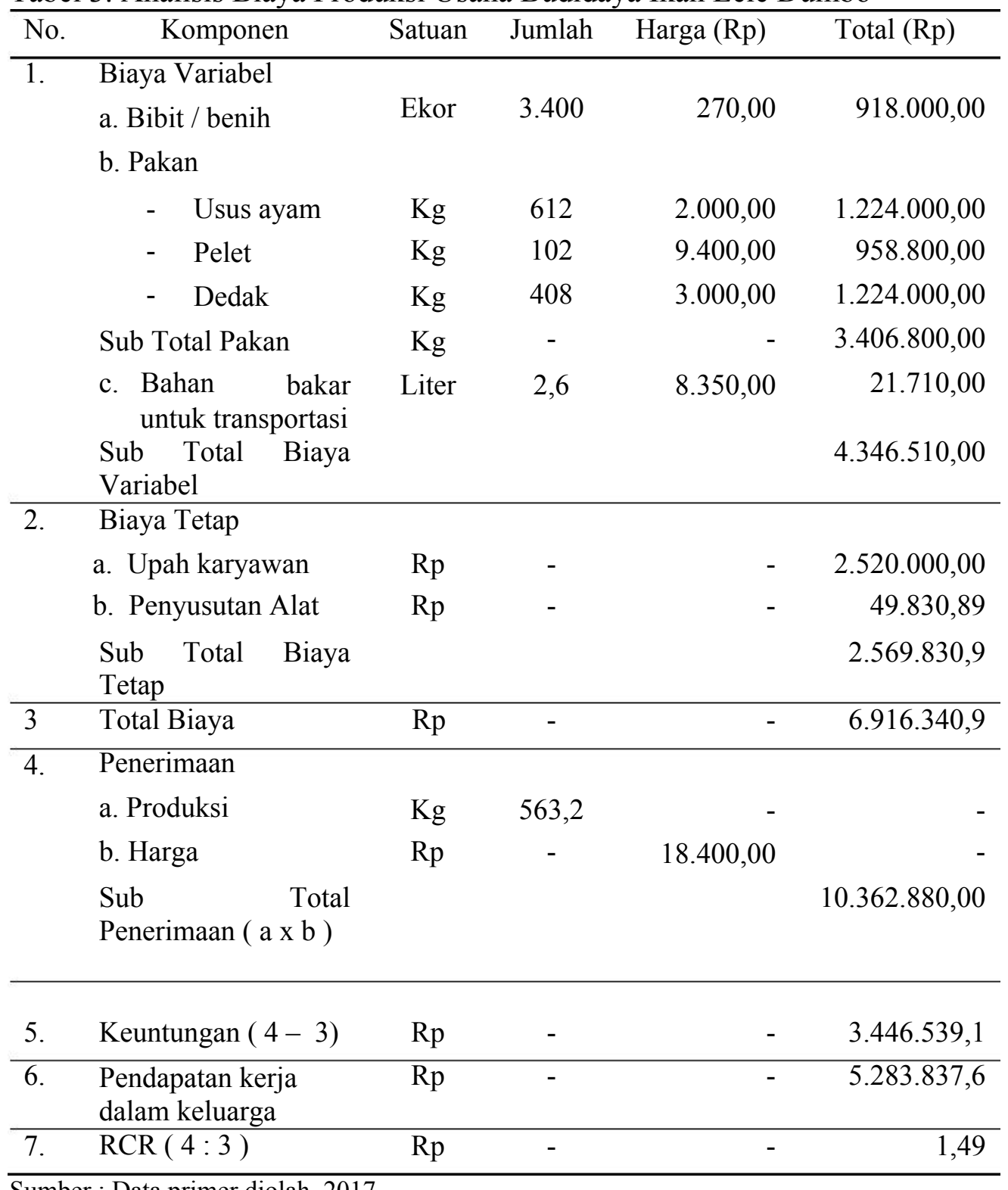

Sumber : Data primer diolah, 2017 


\section{a. Biaya Tidak Tetap}

Pada Tabel 3 menunjukkan bahwa biaya tidak tetap dari usaha budidaya ikan lele dumbo di Kelurahan Tembilahan Hulu adalah sebesar Rp. 4.346.510,00 perproduksidengan rincian biaya diantaranya jumlah rata - rata pembelian bibit adalah 3.400 ekor dengan harga $\mathrm{Rp} 250,00$ per ekornya. Jadi total biaya pembelian bibit adalah Rp 918.000,00 perproduksi. Bibit dibeli langsung dari pedagang bibit / benih ikan. Biaya pakan yang terdiri dari usus ayamdengan rata rata $612 \mathrm{Kg}$ per produksi, dengan harga Rp 2.000,00 per Kg. Jadi total biaya pembelian usus ayam sebesar Rp. 1.224.000,00 Per Produksi, Biaya pakan pelet dengan rata - rata $102 \mathrm{Kg}$ per produksi, dengan harga Rp 9.400,00 per Kg. Jadi total biaya pembelian pellet ikan sebesar Rp. 958.800,00 perproduksi, Biaya pakan dedak dengan rata - rata $408 \mathrm{Kg}$ per produksi, dengan harga Rp 3.000,00 per $\mathrm{Kg}$. Jadi total biaya pembelian Dedak sebesar Rp. 1.224.000,00 perproduksi, dan biaya transportasi selama produksi adalah sebanyak 2,6 liter dengan harga $\mathrm{Rp} 8.350,00$ perliternya. Jadi total biaya transportasi selama produksi sebesar Rp. 21.710,00 perproduksi.

Berdasarkan data diatas dapat dilihat bahwa kontribusi terbesar pada biaya tidak tetap adalah pakan sebesar Rp $\quad 3.406 .800,00$ perproduksi.Hal ini senada dengan penelitian Wibowo ( 2011) yang menunjukan bahwa kontribusi biaya variable terbesar dalam usaha budidaya ikan lele dumbo berasal dari biaya pembelian pakan, yaitu sebesar Rp 775.725,00 perproduksi. Karna biaya pakan paling besar dari pada biaya variable lainnya.

\section{b. Biaya Tetap}

Biaya tetap merupakan biaya investasi awal usaha budidaya lele dumbo seperti kolam terpal dan peralatan lainnya karena paling dibutuhkan dalam produksi. Biaya penyusutan ini dihitung dari masing - masing peralatan yang ditentukan oleh banyaknya masing - masing alat yang digunakan dan umur ekonomisnya. Biaya penyusutan dalam penelitian ini adalah penyusutan alat-alat yang digunakan dalam budidaya ikan lele dumbo, terdiri dari terpal, jaring, ember, papan, palu, tali, bak penampung, cangkul, gerobak, paku.

Pada Tabel 3 menunjukan bahwa biaya tetap terdiri dari biaya penyusutan alat per produksi sebesar Rp. 49.830,89 dan biaya untuk upah karyawan sebesar Rp 2.520.000,00 . Upah diberikan kepada karyawan tersebut per satu kali produksi. Sehingga dapat diketahui biaya tetap sebesar 2.569.830,9 perproduksi. Berdasarkan data diatas dapat dilihat bahwa kontribusi terbesar pada biaya tetap adalah upah karyawan sebesar Rp 2.520.000,00 perproduksi.

\section{c. Total Biaya}

Dari tabel 3 memperlihatkanbahwa total biaya usaha budidaya ikan lele adalah ratarata sebesar Rp. 6.916.340,9 perproduksi, dimana jumlah biaya tetap rata-rata sebesar Rp.2.569.830,9 perproduksidan biaya tidak tetap sebesar Rp.4.346.510 perproduksi. Biaya yang berkontribusi terbesar adalah biaya tidak tetap, hal ini dikarenakan biaya yang paling besar dikeluarkan adalah biaya pakan, karena pemberian pakan rutindiberikan kepada ikan 
agar pertumbuhan ikan lele tidak terganggu. Nafsu makan ikan lele selama masa pertumbuhan sangat tinggi sehingga jika kekurangan pakan sifat dari kanibalisme ikan lele dapat terjadi.

\subsubsection{Penerimaan}

Penerimaan

usaha agroindustri adalah perkalian antara jumlah produksi yang diperoleh dengan harga yang berlaku dipasar (Soekartawi, 1998). Tabel 3 menunjukan bahwa penerimaan yang diperoleh yaitu rata- rata sebesar Rp.10.362.880,00 perproduksi. Penerimaan diperoleh dari harga ikan lele rata- rata Rp. $18.400 / \mathrm{kg}$ dikalikan dengan jumlah produksi ikan lele rata-rata yaitu $563,2 \mathrm{~kg}$ perproduksi.

\subsubsection{Keuntungan}

Keuntungan yang diperoleh usaha budidaya ikan lele dumbo di Kelurahan Tembilahan Hulu merupakan selisih antara total penerimaan dengan total biaya yang dikeluarkan. Untuk mengetahui besarnya keuntungan pada usaha budidaya ikan lele dumbo di Kelurahan Tembilahan Hulu dapat dilihat pada Tabel 3 yang menunjukan bahwa keuntungan yang diperoleh sebesar Rp. 3.446.539,1 perproduksi. Menurut Hernanto (1998), berhasil tidaknya usaha dapat dilihat dari besarnya pendapatan yang diperoleh dalam mengelola suatu usaha. Bagi pengusaha analisis ini membantu mereka dalam mengukur apakah kegiatan usaha mereka pada saat ini berhasil atau tidak.

\subsubsection{Pendapatan Kerja dalam} Keluarga
Menurut Tohir (1983), keberhasilan atau kesuksesan usaha dapat dilihat dari sudut ekonomi yaitu besarnya penghasilan atau pendapatan kerja keluarga.Pendapatan kerja keluarga merupakan imbalan terhadap bunga harta sendiri, upah tenaga kerja keluarga, dan besarnya penghasilan yang di peroleh. Pada tabel 9 dapat dilihat bahwa jumlah pendapatan kerja dalam keluarga rata- rata sebesar Rp. 5.283.837,6 per Produksi. Pendapatan kerja keluarga diperoleh dari pendapatan bersih ditambah dengan upah tenaga kerja dalam keluarga dan penyusutan alat. Besarnya pendapatan tenaga kerja dalam keluarga pada usaha budidaya ikan lele dumbo dikarenakan banyaknya jumlah curahan tenaga kerja dalam keluarga yang digunakan pada usaha ini.

\subsubsection{Efisiensi}

Efisiensi usaha adalah gambaran layak tidaknya usaha tersebut dilakukan atau diusahakan. Menurut Soekartawi (2002), analisis Return Cost $(\mathrm{R} / \mathrm{C})$ ratio merupakan perbandingan (ratio atau nisbah) antara penerimaan (revenue) dan biaya (cost). yang dikeluarkan dalam satu kali produksi.

Dari Table 3 dapat dilihat bahwa usaha budidaya ikan lele dumbo di daerah penelitian layak diusahakan, hal ini dapat dilihat dari besarnya $\mathrm{R} / \mathrm{C}$ yang diperoleh yaitu sebesar 1,49 yang berarti bahwa setiap Rp. 1 biaya yang dikeluarkan untuk usaha budidaya ikan lele akan menghasilkan pendapatan kotor atau penerimaan sebesar Rp. 1,49. Hal ini senada dengan penelitian yang dilakukan oleh Putriana(2014), nilai RCR yang diperoleh adalah sebesar 
1,05 yang berarti usaha budidaya ikan lele dumbo menguntungkan.

\subsection{Analisis SWOT Usaha Budidaya Lele Dumbo}

Berdasarkan hasil penelitian dan pengamatan, diperoleh beberapa data faktor internal yang selengkapnya dapat diamati pada Tabel 4.

Tabel 4. Internal Faktor Analisys Summary

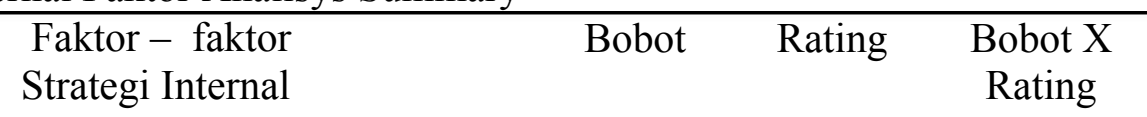

Kekuatan

1. Pengalaman dalam usaha budidaya lele hampir 5 tahun

$0,10 \quad 4 \quad 0,40$

2. Hasil produksi adalah jenis ikan unggulan

$0,12 \quad 3 \quad 0,36$

3. Jarak waktu panen stabil

$0,10 \quad 4 \quad 0,40$

4. Keuangan perusahaan baik karena dari modal sendiri

$0,12 \quad 4 \quad 0,48$

5. Sudah memiliki pelanggan tetap

$\begin{array}{lll}0,12 & 4\end{array}$

6. Lahan cukup luas membuat produksi ikan lele meningkat

$\begin{array}{lll}0,14 & 3 & 0,42\end{array}$

$0,70 \quad 2,54$

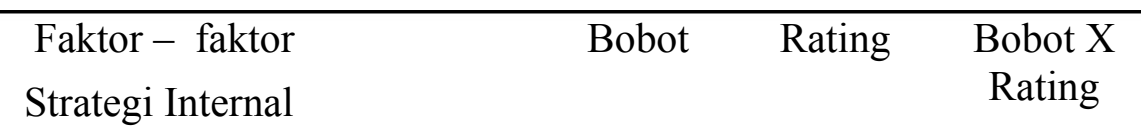

Kelemahan

1. Pengelolaan budidaya yang masih sederhana / tradisional

$\begin{array}{lll}0,10 & 1 & 0,10\end{array}$

2. Belum mampu memproduksi pakan sendiri

$0,12 \quad 1 \quad 0,12$

3. Manajemen produksi ( pemberian pakan ) tidak terkontrol

$\begin{array}{lll}0,10 & 2 & 0,20\end{array}$

4. Kapasitas produksi rendah dan belum mampu menjangkau pasar diluar Tembilahan

$\begin{array}{lll}0,12 & 1 & 0,12\end{array}$

$0,44 \quad 0,54$

Sumber : Data olahan primer, 2017

Berdasarkan hasil analisis bahwa faktor yang menjadi kekuatan matrik IFE pada table 4, menunjukan utama pembudidaya adalah 
Keuangan perusahaan baik karena dari modal sendiri dan sudah memiliki pelanggan tetap dengan nilai sebesar 0,48. Hal ini dikarenakan modal yang dimiliki adalah modal sendiri tanpa harus memikirkan pembayaran tagihan dan bunga ditiap bulannya dan pembudidaya masing - masing telah memiliki pelanggan tetap. Kelemahan utama dari usaha budidaya lele dumbo di kelurahan Tembilahan Hulu Kecamatan Tembilahan Adalah Manajemen produksi ( pemberian pakan ) tidak terkontrol dengan nilai sebesar 0,20. Hal ini dikarenakan pembudidaya tidak memiliki alat yang modern yang dapat member pakan pada ikanyang secara otomatis sehingga ikan tidakakan mengalami keterlambatan pemberian pakan.
Kelemahan utama ini harus dijadikan pertimbangan untuk merubah kebijakan menggunakan alat modern yang dengan begitu dapat membantu pembudidaya sehingga untuk meningkatkan hasil produksi dapat terlaksana.

Nilai persentase skor bobot dari factor internal adalah 3,08. Nilai tersebut menunjukan bahwa usaha budidaya secara internal adalah kuat karna mampu memanfaatkan kekuatannya untuk mengatasi kelemahan yang dimiliki dan terus meningkatkan kinerja dengan cara mengatasi kelemahan utama yang menjadi kendala.

Berdasarkan hasil penelitian dan pengamatan, diperoleh beberapa data factor eksternal yang selengkapnya dapat diamati pada Tabel 5.

Tabel 5. Eksternal Faktor Analisys Summary

\begin{tabular}{|c|c|c|c|}
\hline $\begin{array}{c}\text { Faktor - faktor } \\
\text { Strategi Eksternal }\end{array}$ & Bobot & Rating & $\begin{array}{c}\text { Bobot X } \\
\text { Rating }\end{array}$ \\
\hline \multicolumn{4}{|l|}{ Peluang } \\
\hline $\begin{array}{l}\text { 1. Ikan lele mengandung banyak zat } \\
\text { gizi }\end{array}$ & 0,14 & 4 & 0,56 \\
\hline $\begin{array}{l}\text { 2. Banyaknya permintaan ikan lele } \\
\text { untuk usaha warung makan }\end{array}$ & 0,11 & 3 & 0,33 \\
\hline \multirow[t]{2}{*}{$\begin{array}{l}\text { 3. Akses jalan dan transportasi yang } \\
\text { mudah diakses sehingga } \\
\text { memudahkan dalam } \\
\text { mendistribusikan produk } \\
\text { kekonsumen }\end{array}$} & 0,14 & 3 & 0,42 \\
\hline & 0,39 & & 1,31 \\
\hline \multicolumn{4}{|l|}{ Ancaman } \\
\hline 1. Tingkat persaingan tinggi & 0,11 & 1 & 0,11 \\
\hline $\begin{array}{l}\text { 2. Isu yang beredar mengenai ikan } \\
\text { lele mengandung zat pembunuh sel } \\
\text { kanker }\end{array}$ & 0,11 & 1 & 0,11 \\
\hline $\begin{array}{l}\text { 3. Harga bahan pakan yang terus } \\
\text { meningkat }\end{array}$ & 0,14 & 2 & 0,28 \\
\hline \multirow[t]{2}{*}{$\begin{array}{l}\text { 4. Kecendrungan masyarakat terhadap } \\
\text { ikan lain }\end{array}$} & 0,11 & 1 & 0,11 \\
\hline & 0,47 & & 0,61 \\
\hline
\end{tabular}


Berdasarkan hasil analisis matrik EFE pada table 5, menunjukan bahwa factor yang menjadi Peluang utama pembudidaya adalah ikan lele mengandung banyak gizi dengan nilai sebesar 0,56 . Hal ini dikarenakan ikan lele merupakan ikan yang memiliki kualitas vitamin yang sangat dibutuhkan oleh tubuh.. ancaman utama dari usaha budidaya lele dumbo di kelurahan Tembilahan Hulu Kecamatan Tembilahan Adalah harga pakan yang terus meningkat dengan nilai sebesar 0,28.

Nilai persentase skor bobot dari factor eksternal adalah 1,92. Nilai tersebut menunjukan bahwa usaha budidaya secara Eksternal adalah sedang karna dalam usaha budidayanya menjalani strategi yang memanfaatkan peluang dan menghindari ancaman.

\subsection{Strategi Pengembangan Usaha Budidaya Ikan Lele}

Berdasarkan analisis IFAS dan EFAS pengembangan usaha budidaya ikan lele dumbo di Kelurahan Tembilahan Hulu Kecamatan Tembilahan dapat dijelaskan sebagai berikut :

1. Faktor internal strategi pemasaran yang meliputi Strengths (kekuatan) dan weaknesses (kelemahan) menunjukan bahwa nilai dari Strengths (kekuatan) adalah 2,54 dan weaknesses (kelemahan) adalah 0,54 sehingga total keseluruhan dari factor intenal adalah 3,08

2. Factor eksternal yang meliputi Opportunities (peluang) dan Treath (ancaman) menunjukan bahwa nilai dari Opportunities (peluang) adalah 1,31 dan Treath (ancaman) adalah 0,61, sehingga total dari keseluruhan dari factor eksternal adalah 1,92

Dari data diatas dapat dilihat pada antara factor internal Strengths (kekuatan) sebesar 2,54dan kelemahan sebesar 0,54.Hal ini berarti factor kekuatan harus dijadikan sebagai langkah strategi dalam meningkatkan strategi pengembangan usaha budidaya lele dumbo ini. Sementara factor kelemahan sebesar 0,54 harus diminimalisir dengan cara memperkuat system strategi pengembangan usaha yang mampu mengurangi factor resiko dalam strategi pengembangan usaha budidaya ikan lele dumbo.

Sementara itu pada factor eksternal Peluang sebesar 1,31 merupakan kondisi yang cukup menguntungkan bagi pembudidaya untuk mengembangkan usaha budidaya ikan lele karna factor ancaman lebih kecil yaitu 0,61. Dalam kondisi ini pembididaya harus mampu mempertahankan kondisi peluang saat ini, dan terus meminimalisir ancaman sehingga peluang strategi pengembangan dapat terus meningkat. Factor ancaman sebesar 0,61 ini menunjukan bahwa strategi pemasaran memiliki resiko yang besar.

Dari hasil tabulasi analisa SWOT, maka budidaya ikan lele di kelurahan Tembilahan Hulu Kecamatan Tembilahan Kabupaten Indragiri Hilir sebagai berikut : 


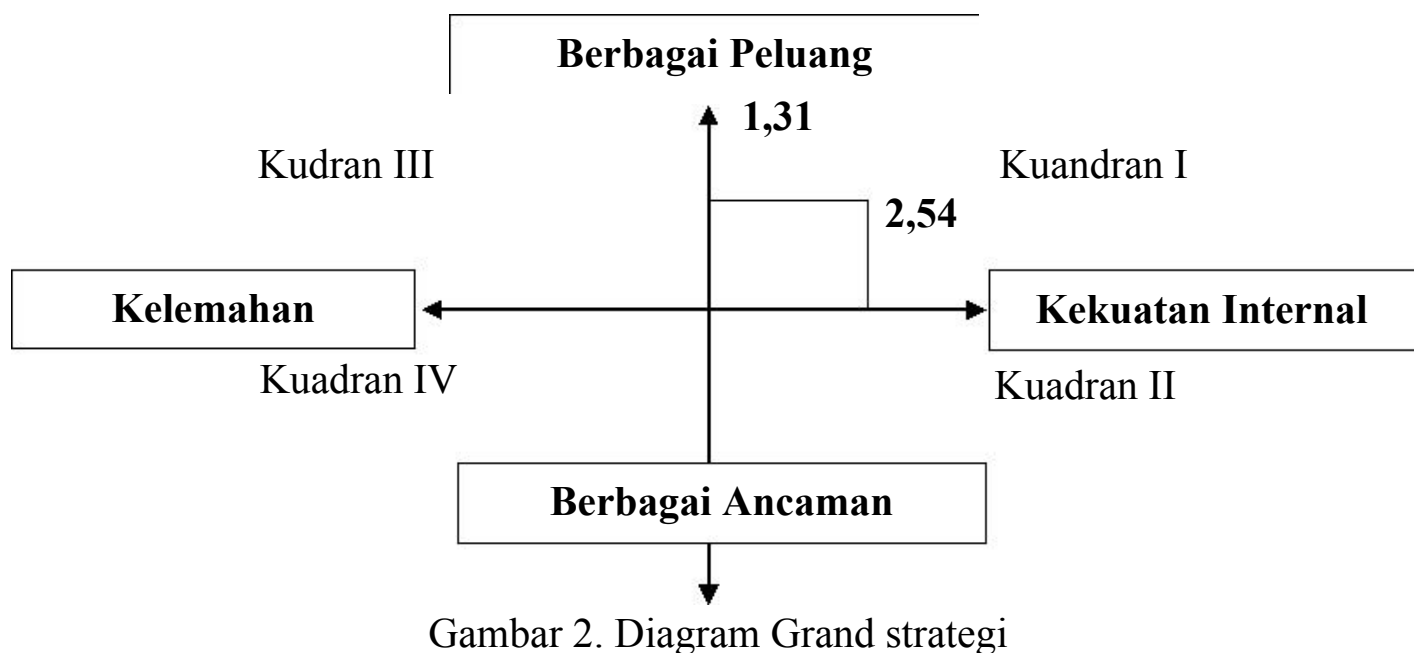

Berdasarkan diagram strategi diatas, maka strategi yang terdapat pada pengembangan usaha budidaya adalah SO (Strenght dan Opportunities)yang terletak pada kuadran I. Strategi yang harus diterapkan untuk perusahaan yang berada pada posisi ini adalah mendukung kebijakan pertumbuhanyangagresif,

pengembangan pasar, penetrasi pasar, pengembangan produk, integrasi kedepan, integrasi kebelakang, integrasi horizontal dan disersifikasi konsentrik.

Strategi SO merupakan situasi yang paling menguntungkan. Pembudidaya memiliki peluang dan kekuatan, sehingga dapat memanfaatkan peluang sebesar besarnya. Strategi ini mampu mengembangkan usaha budidaya karna dengan banyaknya permintaan terhadap produk sehingga pembudidaya telah memiliki pelanggan yang tetapdan juga lahan yang luas memiliki dampak kepada jarak panen yang cenderung stabil dan dapat berproduksi terus menerus.

\section{KESIMPULAN DAN SARAN}

\subsection{Kesimpulan}

1. Rata-rata jumlah biaya yang dikeluarkan adalah sebesar Rp. 6.916.340,9 per produksi sedangkan Rata-rata pendapatann yang diperoleh sebesar Rp. 10.362.880,00per Produksi, sehingga diperoleh keuntungan rata-rata sebesar Rp.3.446.539,1 per produksi.Nilai efisiensi atau $\mathrm{R} / \mathrm{C}$ yang diperoleh adalah sebesar 1,49 yang berarti bahwa setiap Rp. 1 biaya yang dikeluarkan untuk usaha budidaya ikan lele akan menghasilkan pendapatan kotor atau penerimaan sebesar Rp. 1,49 dan pendapatan bersih atau keuntungan sebesar Rp. 0,49 . Hal ini menunjukan bahwa usaha budidaya ikan lele dumbo di Kelurahan Tembilahan Hulu Kecamatan Tembilahan efisien atau layak diusahakan.

2. Strategi pengembangan usaha yang digunakan oleh pembudidaya lele dumbo adalah strategi SO. Strategi SO ( Strengh Opportunity ) adalah 
strategi yang digunakan untuk memanfaatkan peluang yang ada dengan memanfaatkan kekuatan yang dimiliki oleh perusahaan

\subsection{Saran}

1. Pembudidaya dapat terus meningkatkan produksi ikan lele dikarenakan semakin banyaknya warung makan yang menyediakan menu ikan leleakan semakin meningkatkan permintaan pasar sehingga dapat pula meningkatkan pendapatan bagi pembudidaya ikan lele dumbo.

2. Perlu adanya perhatian pemerintah baik itu penyuluhan tentang teknologi terbaru, teknik budidaya maupun bantuan dana terhadap budidaya ikan lele dumbo ini agar dapat berkembang dengan lebih baik lagi

\section{DAFTAR PUSTAKA}

Anonim. 2002. Lele : Ikan Berkumis Paling Populer. Agromedia Pustaka. Jakarta.

David, F R. 2004. Manajemen Strategis Konsep-Konsep. Terjemahan. PT. Indeks Kelompok Gramedia. Jakarta.

Departemen Kelautan dan Perikanan. 2007. Budidaya Lele Sangkuriang. http ://www.dkp.go.id/content.php? $\mathrm{c}=2558$.

Freddy. 2006. Penuntun Kepada Gizi Yang Baik Dalam Rumah Tangga Dan Kesehatan. Penebar Swadaya. Jakarta.

Fadholi, H, 1989. Ilmu Usahatani. Penebar Swadaya. Jakarta. 